\title{
Response of grasslands conversion to croplands on soil organic carbon in Bashang area of Northern China
}

\author{
Hong-Lai Liu ${ }^{1,2 \#}$, Jun-Wei Wang ${ }^{1,2 \#}$, Jin-Ying Lv ${ }^{1}$ and Kun Wang ${ }^{1,2 *}$ \\ ${ }^{1}$ College of Animal Science and Technology, China Agricultural University, Beijing, 100193, China \\ ${ }^{2}$ Guyuan National Grassland Ecosystem Field Station, Guyuan County, Hebei province, 076550, China. \\ Accepted 25 February, 2010
}

\begin{abstract}
This study investigated the effects of two types of grasslands conversion to croplands on soil organic carbon (SOC) in Bashang area where it is a typical agro-pastoral ecotone of Northern China using a pare-site method. The results showed that the SOC contents and densities decreased with increasing soil depth. The soil bulk density and SOC content significantly decreased in the upper horizon after the grasslands was converted into croplands. The SOC densities were approximately $2.3-2.7$ and $4.2-9.1 \mathrm{~kg}$ $\mathrm{C} \mathrm{m}^{-2}$ in the upper horizons of site 1 and site 2, respectively, with significant differences between grasslands and croplands. The SOC densities up to $60 \mathrm{~cm}$ depth were much higher in site 2 (intrazonal grassland-cropland) than in site 1 (zonal grassland-cropland), reaching approximately $13.24-22.49$ and $5.36-6.49 \mathrm{~kg} \mathrm{C} \mathrm{m}^{-2}$, respectively. The conversion of grasslands to croplands induced a moderate loss of SOC, with a range of -4 to $55 \%$ for the $0-60 \mathrm{~cm}$ depth over about 20 -year period. To conserve the present status, potential conversion should be banned in both zonal and intrazonal grassland, the zonal grassland should be enforced "turning cropland to grassland" policy, and the intrazonal grassland be reasonably used.
\end{abstract}

Key words: Agro-pastoral ecotone, conversion, land use, soil organic carbon, zonal and intrazonal grasslands.

\section{INTRODUCTION}

The anthropogenic $\mathrm{CO}_{2}$ emission into the atmosphere plays an important role in driving global climate change, and the atmospheric $\mathrm{CO}_{2}$ concentrations have increased by $31 \%$ since 1970 according to the intergovernmental panel on climate change (IPCC) (Falkowski et al., 2000). Apart from the burning of fossil fuel, land-use conversion is seen to be having a significant impact on global carbon balance by altering land cover, biota and biogeochemical cycles (Honghton et al., 1999). An important strategy for combating the rise in atmospheric $\mathrm{CO}_{2}$ concentrations is to enhance carbon sequestration in the terrestrial ecosystems, which is cost-effective and environmentally beneficial (Wang et al. 2008). Soil plays an essential role in the global carbon cycle, and it may act as a source or sink of $\mathrm{CO}_{2}$ in exchange with the atmosphere; because the soil carbon pool has been estimated at approximately

*Corresponding author. E-mail: wangkcau@hotmail.com. Tel /Fax: +81 1062733338 .

\#These authors contributed equally to this paper
3.3 times the size of the atmospheric pool and 4.5 times the size of the biotic pool (Lal, 2004). Studies addressing SOC dynamic when land is converted from one use to another would be valuable in improving our understanding and increasing our predictive capacity over both short and long time-scales. Quantifying changes in soil carbon may be important for land uses. Some studies have estimated the contribution of forestation to the global carbon cycle at both regional and global scales (Zhang and Xu, 2003; Evrendilek et al., 2004). Others were concerned with the characteristics of the current carbon pool of ecosystems and the effect of farmland and grassland managements on SOC (Lal, 2002; Chen et al., 2007). However, limited attention has been paid to the effect of land use conversion on soil carbon sequestration in Bashang area of Northern China, where it is an agro-pastoral ecotone of Northern China.

The agro-pastoral ecotone of Northern China covers 13 provinces with up to $1.2 \times 10^{5} \mathrm{~km}^{2}$ from the Northern China Plain to the Inner Mongolia Plateau (Han et al., 2004). This transitional zone from Eastern agriculture to Western pastures, from monsoons to the continental climate and from humid to semiarid zones is affected by 


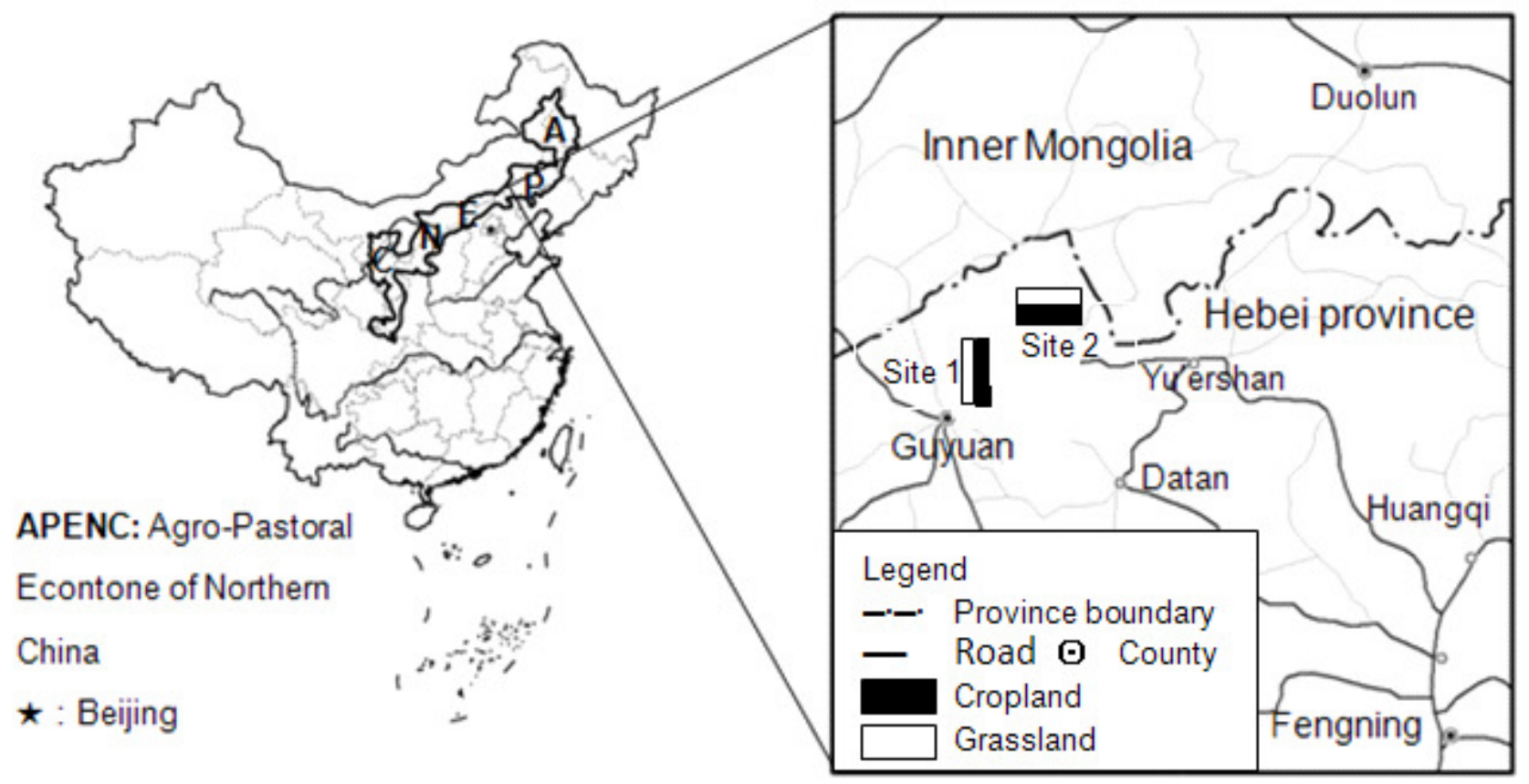

Figure 1. Map of the agro-pastoral ecotone in Northern China and in the studied area.

natural disasters and intensified human activities (Chen and Zhu, 2001). The region is an important source of food and diary products and an ecological barrier for Eastern and middle China. However, the expanding human population and changing lifestyles have contributed to the widespread conversion of grasslands into croplands, and to ecosystem degradation in the region due to intensive land use (Zhao et al., 2000).

The Bashang area is one of the most representative geographical areas in the agro-pastoral ecotone of Northern China (Liu et al., 2009). Most prior investigations into the conversion of cultivated grasslands into croplands focused on zonal grasslands; however, the intrazonal grasslands within the zonal grasslands have been ignored (Su et al., 2009). The present study using a paired-site approach performed field samplings in the Bashang area to assess the effects of zonal and intrazonal grasslands conversion to croplands on SOC. We then forward effective land management for protecting SOC loss from land use in this region.

\section{MATERIALS AND METHODS}

\section{Region and site description}

The study area is in Guyuan County, Hebei Province, North China $\left(41^{\circ} 46^{\prime} \mathrm{N}, 115^{\circ} 41^{\prime} \mathrm{E}\right)$, along the southeast Inner Mongolia plateau that connects with the Xilin Gol steppes (Figure 1). Guyuan County has $1.4 \times 10^{3} \mathrm{~km}^{2}$ of natural grasslands, of which the zonal and intrazonal grasslands occupy 76 and $24 \%$, respectively, according to the Guyuan Agricultural Bureau. The intrazonal grasslands are in a mosaic distribution in the zonal grasslands. The detailed description for this region can be found in Chen and Zhu, (2001) and Liu et al.
(2009). In brief, this region's climate is semiarid, continental and temperate with monsoons. The annual mean temperature is $2.1^{\circ} \mathrm{C}$, the frost-free period is about $80-110$ days a year and $\geq 10^{\circ} \mathrm{C}$ annual accumulated temperature is $1,500-2,200^{\circ} \mathrm{C}$. Mean annual precipitation ranges from 350 to $450 \mathrm{~mm}$, the average annual potential evaporation is 1,700 to $2,300 \mathrm{~mm}$. Geomorphologically, the region is characterized by open flat lands alternating with undulating hills. The soil is a chestnut type (that is, calcic kastanozems, which is equivalent to calcic-orthic aridisol in the U.S. soil taxonomy classification system) in the top $40 \mathrm{~cm}$ layer and a mixture of sandy soil and gravels below $40 \mathrm{~cm}$ (Chen and Zhu, 2001; Liu et al., 2009).

A paired-site design was used to compare the changes of soil properties between grasslands and croplands. Grasslands are the most important land cover in the agro-pastoral ecotone of Northern China, while croplands are the derivation of reclaimed grasslands in the 1970-1990s. We determined that the zonal and intrazonal grasslands are the two representative types. Hence, two paired sites with different soils and vegetation characteristics were selected based on the availability of reliable information on land use history under the same environmental conditions (Figure 1). The cultivated lands had similar crop and soil management and grow some autumn crops, despite the short growth period. The cropland sites were cultivated to a depth of $20 \mathrm{~cm}$ using a minitype mouldboard plough powered by a horse or a tractor, followed by crop sowing, harrowing and rolling. Annual tillage was once prior to crop sowing. No manure was used, and only a small quantity of inorganic fertilizers was applied annually (average level: $\mathrm{N}, 80 \mathrm{~kg} \mathrm{ha}^{-1} ; \mathrm{P}_{2} \mathrm{O}_{5}, 30 \mathrm{~kg} \mathrm{ha}^{-1}$ ). The natural grasslands were continuously grazed by sheep and dairy cattle.

Site 1 is located in the zonal grasslands, which are covered mainly (35\%) by Stipa krylovii, Stipa baicalensis, Artemisia frigida, Agropyron cristatum, Leymus chinensis and Potentilla acaulis. The croplands were reclaimed from zonal grasslands in about 1988 and planted with Avena chinensis, Dodartia orientalis and maize in a fallow rotation system. The site exhibited sandy chestnut soils with two distinct soil horizons: the upper horizon and the underlying horizon. The distance of the sampling points between the grasslands and the croplands was beyond $50 \mathrm{~m}$, which avoided the influence 
zone of the grasslands-croplands boundary.

Site 2 is located in the intrazonal grassland that was covered mainly $(80 \%)$ by Stipa grandis, L. chinensis, Fillifolium sibiricum, Carex tristachya, Oxytropis coerulea (pall.) DC and Saussurea nivea. The site has fertile chernozem soil with an upper humic horizon of about $40 \mathrm{~cm}$. Cropland was derived from the reclamation of a meadow in 1990 that was planted with $A$. chinensis and $D$. orientalis. The distance between the sampling points was beyond $50 \mathrm{~m}$.

\section{Soil sampling and analysis}

Soil samples were collected in May 2008, before spring cultivation and sowing. At each site, three $20 \times 20 \mathrm{~m}$ sampling locations spaced at least $40 \mathrm{~m}$ apart were demarcated and are hereafter regarded as field replicates. At each location, soil samples from $0-20,20-40$ and $40-60 \mathrm{~cm}$ layers were collected from 10 points using a soil auger, then mixed and pooled as one composite sample. Soil samples were air-dried and sieved through a screen with 2-mm openings. Roots and other debris were removed from the soil and discarded. Particle size distribution was determined by the pipette method in a sedimentation cylinder using sodium hexamethaphosphate as the dispersing agent (ISSCAS 1978).

Soil cores $\left(100 \mathrm{~cm}^{3}\right.$ in volume) were taken from each plot to determine for soil bulk density. Soil bulk densities were determined by drying soil samples at $105^{\circ} \mathrm{C}$. Soil temperature was measured using temperature sensor (ESS-T1, made by Ecotron Scientific Inc. in China). Part of each sample was finely ground to pass through a $0.25 \mathrm{~mm}$ sieve and analyzed for soil organic carbons (SOCs) and total nitrogen (TN) by the Walkley-Black dichromate oxidation procedure (Nelson and Sommers, 1982) and by the Kjeldahl procedure (UDK140 Automatic steam distilling unit, Automatic Titroline 96, Italy), respectively (ISSCAS, 1978). Inorganic N $\left(\mathrm{NH}_{4}{ }^{+}-\mathrm{N}\right.$ and $\mathrm{NO}_{3}{ }^{-}-\mathrm{N}$ ) was extracted with $0.01 \mathrm{~mol} \mathrm{I}^{-1} \mathrm{CaCl}_{2}$ (Dilly et al., 2003) and measured using automated flow injection analysis (TRAACS 2000, Bran and Luebbe, Norderstedt, Germany). The dissolved organic carbon (DOC) was distilled by ultrapure water; the ratio of water and soil was 5:1. The DOC content was analyzed by a total organic carbon analyzer (elementary liquid TOC).

\section{Calculation of SOC density and statistical analysis}

Since SOC content varies along soil profile, SOC density is calculated as follows:

SOC Density $=\sum_{i=1}^{n}$ Di $\times \mathrm{Bi} \times \mathrm{Oi}$

where $\mathrm{n}$ is the number of soil horizons, $\mathrm{Di}$ is the depth interval $(\mathrm{cm})$ of the horizon I from the top soil and down on, $\mathrm{Bi}$ is the bulk density $\left(\mathrm{g} \mathrm{cm}^{-3}\right)$ in the horizon I and Oi is the mean SOC content (\%) in the horizon i.

Since each grassland type and its reclamation area were at one location and not replicated, we followed the approach of Frank et al. (1995) and considered each of the three plots as a replication of summary statistics. Each variable of the three plots was averaged for statistical analysis. Then, one-way analysis of variance (ANOVA) procedures was used to detect the differences between means of parameters examined for the three sites. The least significant difference (LSD) determined the significance of treatment means at $p<0.05$

\section{RESULTS}

Table 1 lists the characteristics of soil bulk density, soil organic carbon and nitrogen and soil temperature in two paired sites. The bulk density increased with depth, it was significantly higher in croplands than in grasslands except $40-60 \mathrm{~cm}$ layer, and the bulk density of site 1 was higher than that of site 2 accordingly. The SOC content decreased generally with increasing soil depth, and the conversion remarkably caused the decline of SOC content of grasslands with exception of $40-60 \mathrm{~cm}$ layer. The total nitrogen had similar trend with SOC's change. The soil temperature evidently increased after the grasslands converted with exception of $40-60 \mathrm{~cm}$ layer. On a dry soil mass basis, the average ratios of SOC: TN in croplands and grassland in site 1 were approximately 10 , which was higher than grassland in site 1 . The SOC densities were approximately $2.3-2.7$ and $4.2-9.1 \mathrm{~kg} \mathrm{C} \mathrm{m}^{-2}$ in the upper horizons of site 1 and site 2, respectively (Figure 2). The SOC densities up to $60 \mathrm{~cm}$ depth were approximately $5.4-6.5$ and 13.2 $22.5 \mathrm{~kg} \mathrm{C} \mathrm{m}^{-2}$, where there were significant differences between the land uses.

\section{DISCUSSION}

Cultivation increased the soil bulk density to 0.11 to $0.16 \mathrm{~g}$ $\mathrm{cm}^{-3}$ and 0.06 to $0.24 \mathrm{~g} \mathrm{~cm}^{-3}$ in the plough layer $(0-20$ $\mathrm{cm})$ and plough pan layer $(20-40 \mathrm{~cm})$ in the studied area. The changes apparently related to the effects of accelerated wind erosion due to cultivation and subsequent tillage practices. Cultivated rain-fed croplands had a short growth period and low vegetative and root biomass in Bashang area. The farmers harvested the above-ground biomass, including the seeds and the straw in autumn. Therefore, the cropland surfaces were left fallow from early October to late May of the following year and were directly exposed to strong wind erosion, especially in the spring from the thawing of the surface soil to the germination of crop seeds (Xu, 1997; Li et al., 2004). Wind erosion is associated with a deficiency of soil moisture, which has a direct influence on the wind velocity required to initiate soil movement, as only relative dry soil particles are likely to be moved by the wind (Chepil, 1956; Hai et al., 2005). Therefore, the croplands converted from zonal grasslands were more susceptible to wind erosion compared with the intrazonal grasslands. Some other researchers have also reported an increase in bulk density due to cultivation (Srivastava and Singh, 1989; Nimisha and Sigh, 2007).

There exists an inverse relationship between soil bulk density and SOC content (Davidson et al., 1967). The amount of organic matter present in soil and the rate of SOM turnover is influenced by agricultural management practice. Because SOM is composed of a series of fractions, management practices will also influence the distribution of organic $\mathrm{C}$ and $\mathrm{N}$ among SOM pools (Cambardella, 1994). Cropping decreased the mean soil organic carbon by about $44 \%$ in the upper horizon $(0-40 \mathrm{~cm})$, while the underlying horizon was not affected much. Hence, the conversion of grasslands to croplands often induced loss 
Table 1. Characteristics of bulk density, soil organic carbon, total nitrogen and temperature in two paired sites.

\begin{tabular}{|c|c|c|c|c|c|}
\hline \multirow{2}{*}{$\begin{array}{c}\begin{array}{c}\text { Horizon } \\
\text { depth }\end{array} \\
\end{array}$} & \multirow{2}{*}{ Parameters } & \multicolumn{2}{|c|}{ Site 1} & \multicolumn{2}{|c|}{ Site 2} \\
\hline & & Grassland & Cropland & Grassland & Cropland \\
\hline \multirow{7}{*}{$0-20 \mathrm{~cm}$} & Bulk density $\left(\mathrm{g} \mathrm{cm}^{-3}\right)$ & $1.28 \pm 0.02 b$ & $1.42 \pm 0.03 a$ & $1.07 \pm 0.02 b$ & $1.13 \pm 0.01 a$ \\
\hline & $\operatorname{SOC}\left(\mathrm{g} \mathrm{kg}^{-1}\right)$ & $10.60 \pm 0.81 a$ & $8.10 \pm 0.63 b$ & $42.41 \pm 2.22 a$ & $18.70 \pm 1.73 b$ \\
\hline & $\mathrm{TN}\left(\mathrm{g} \mathrm{kg}^{-1}\right)$ & $2.63 \pm 0.29 a$ & $0.74 \pm 0.08 b$ & $3.98 \pm 0.13 a$ & $1.86 \pm 0.07 b$ \\
\hline & Inorganic $\mathrm{N}\left(\mathrm{mg} \mathrm{kg}^{-1}\right)$ & $6.80 \pm 0.24 a$ & $5.17 \pm 0.12 b$ & $6.35 \pm 0.24 b$ & $14.29 \pm 0.86 a$ \\
\hline & $\mathrm{NH}_{4}{ }^{+}-\mathrm{N}\left(\mathrm{mg} \mathrm{kg}^{-1}\right)$ & $1.21 \pm 0.13 a$ & $1.01 \pm 0.02 a$ & $1.29 \pm 0.06 a$ & $1.16 \pm 0.02 a$ \\
\hline & $\mathrm{NO}_{3}-\mathrm{N}\left(\mathrm{mg} \mathrm{kg}^{-1}\right)$ & $5.59 \pm 0.21 a$ & $4.16 \pm 0.10 b$ & $5.06 \pm 0.18 a$ & $13.13 \pm 0.84 a$ \\
\hline & Temperature $\left({ }^{\circ} \mathrm{C}\right)$ & $17.90 \pm 0.75 b$ & $19.80 \pm 0.48 a$ & $15.19 \pm 0.63 b$ & $16.83 \pm 0.32 a$ \\
\hline \multirow{7}{*}{$20-40 \mathrm{~cm}$} & Bulk density $\left(\mathrm{g} \mathrm{cm}^{-3}\right)$ & $1.48 \pm 0.01 b$ & $1.59 \pm 0.02 a$ & $1.30 \pm 0.0 \mathrm{~b}$ & $1.54 \pm 0.1 \mathrm{a}$ \\
\hline & $\operatorname{SOC}\left(\mathrm{g} \mathrm{kg}^{-1}\right)$ & $7.24 \pm 1.93 a$ & $4.90 \pm 0.87 b$ & $31.97 \pm 2.65 a$ & $11.97 \pm 0.83 b$ \\
\hline & $\mathrm{TN}\left(\mathrm{g} \mathrm{kg}^{-1}\right)$ & $1.58 \pm 0.12 a$ & $0.53 \pm 0.06 b$ & $3.23 \pm 0.08 a$ & $1.21 \pm 0.06 b$ \\
\hline & Inorganic $\mathrm{N}\left(\mathrm{mg} \mathrm{kg}^{-1}\right)$ & $11.48 \pm 0.99 a$ & $2.82 \pm 0.13 b$ & $4.56 \pm 0.27 b$ & $10.66 \pm 0.75 a$ \\
\hline & $\mathrm{NH}_{4}^{+}-\mathrm{N}\left(\mathrm{mg} \mathrm{kg}^{-1}\right)$ & $0.82 \pm 0.03 a$ & $1.11 \pm 0.08 a$ & $0.95 \pm 0.03 a$ & $1.09 \pm 0.02 a$ \\
\hline & $\mathrm{NO}_{3}^{-}-\mathrm{N}\left(\mathrm{mg} \mathrm{kg}^{-1}\right)$ & $10.66 \pm 0.92 a$ & $1.71 \pm 0.05 b$ & $3.61 \pm 0.24 b$ & $9.57 \pm 0.73 a$ \\
\hline & Temperature $\left({ }^{\circ} \mathrm{C}\right)$ & $15.31 \pm 0.56 b$ & $17.14 \pm 0.68 a$ & $13.17 \pm 0.38 b$ & $14.35 \pm 0.23 a$ \\
\hline \multirow{7}{*}{$40-60 \mathrm{~cm}$} & Bulk density $\left(\mathrm{g} \mathrm{cm}^{-3}\right)$ & $1.61 \pm 0.02 a$ & $1.63 \pm 0.01 a$ & $1.47 \pm 0.01 \mathrm{a}$ & $1.43 \pm 0.00 a$ \\
\hline & $\operatorname{SOC}\left(\mathrm{g} \mathrm{kg}^{-1}\right)$ & $5.06 \pm 0.65 a$ & $4.60 \pm 0.04 a$ & $17.34 \pm 0.08 a$ & $18.61 \pm 0.10 a$ \\
\hline & $\mathrm{TN}\left(\mathrm{g} \mathrm{kg}^{-1}\right)$ & $0.88 \pm 0.04 a$ & $0.21 \pm 0.02 b$ & $1.85 \pm 0.07 a$ & $1.69 \pm 0.11 a$ \\
\hline & Inorganic $\mathrm{N}\left(\mathrm{mg} \mathrm{kg}^{-1}\right)$ & $23.27 \pm 1.61 \mathrm{a}$ & $2.32 \pm 0.12 b$ & $3.61 \pm 0.37 b$ & $7.52 \pm 1.72 a$ \\
\hline & $\mathrm{NH}_{4}{ }^{+}-\mathrm{N}\left(\mathrm{mg} \mathrm{kg}^{-1}\right)$ & $0.76 \pm 0.05 b$ & $1.12 \pm 0.04 a$ & $0.90 \pm 0.11 a$ & $0.97 \pm 0.09 a$ \\
\hline & $\mathrm{NO}_{3}^{-}-\mathrm{N}\left(\mathrm{mg} \mathrm{kg}^{-1}\right)$ & $22.51 \pm 1.56 a$ & $1.20 \pm 0.08 b$ & $2.71 \pm 0.26 b$ & $16.55 \pm 1.63 a$ \\
\hline & Temperature $\left({ }^{\circ} \mathrm{C}\right)$ & $10.28 \pm 0.65 a$ & $10.36 \pm 0.30 a$ & $9.39 \pm 0.12 a$ & $9.80 \pm 0.27 a$ \\
\hline
\end{tabular}

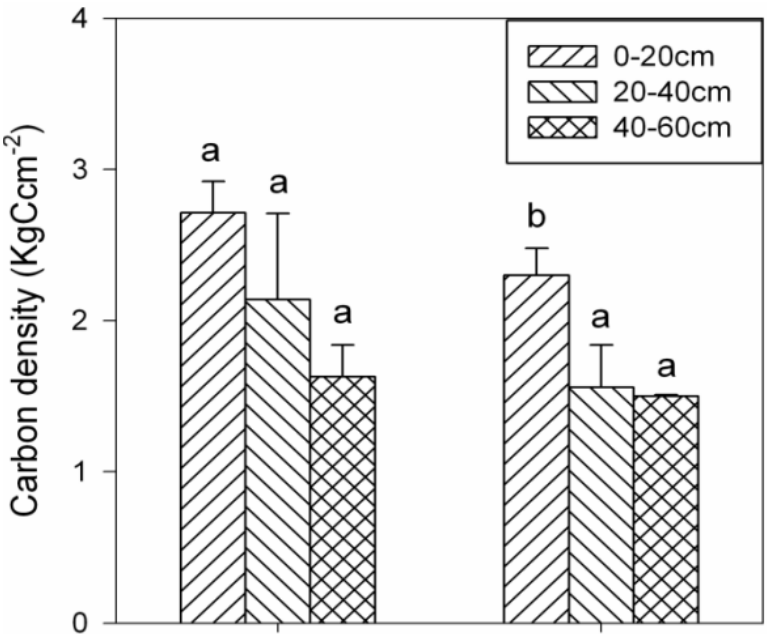

Grassland in Site $1 \quad$ Cropland in Site 1

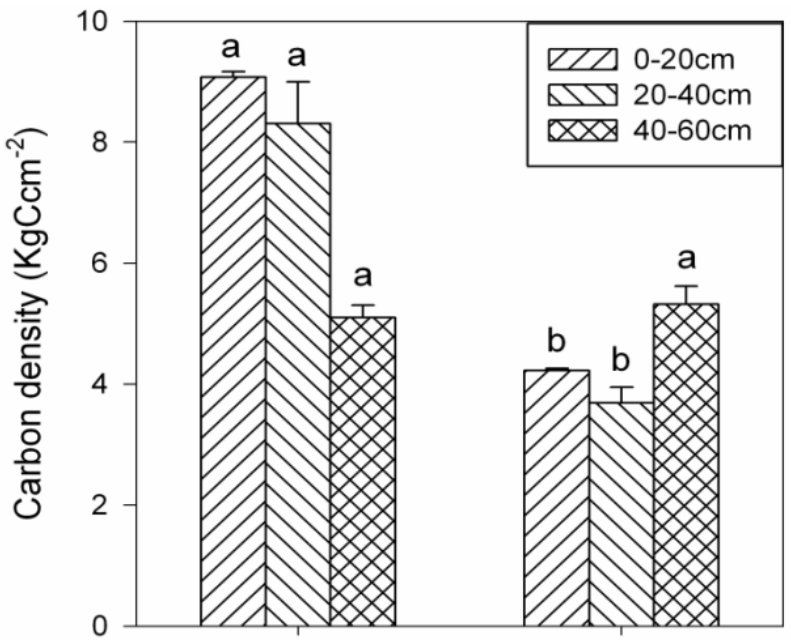

Grassland in Site $2 \quad$ Cropland in Site 2

Figure 2. Distributions of soil organic carbon density $\left(\mathrm{kg} \mathrm{C} \mathrm{m}^{-2}\right)$ in the soil horizons of paired sites. Value is mean $\pm S E(n=3)$. Different letters represent significant difference between grassland and cropland for each site $(P<0.05)$.

of SOC in Bashang area of Northern China and the result agreed with the historical conversion of land-use from native vegetation to agriculture, resulting in sharp declines in soil organic C (Wilson, 1978; Raiesi, 2006). Investigations in Xilin Gol and Inner Mongolia of China, as well as in Northwestern New South Wales, all observed the same trend (Xiao et al., 1998; Su et al., 2009). However, the decreasing rates differed because the principal factors responsible for the depletion or removal of SOC and the initial values probably differed. The DOC content, though, 
had changes similar to those of the SOC.

The SOC densities were determined separately in three distinct soil horizons: the plough horizon $(0-20 \mathrm{~cm})$, the plough pan horizon $(20-40 \mathrm{~cm})$ and the underlying horizon $(40-60 \mathrm{~cm})$ (Figure 2). The plough layer soils were susceptible to changes in the land uses and climate. In the two sites, the SOC densities decreased 15 and $53 \%$ in the croplands and they were significantly lower than in the grasslands at $0-20 \mathrm{~cm}$. The underlying horizons are relatively less affected by moderate cultivations owing to the underlying horizon which usually exist in the SOC with more adamant component. Therefore, the SOC densities lacked significant difference between the underlying horizons of the land uses in each sites. The croplands had SOC loses with a range of -4 to $56 \%$ compared to the grasslands, particularly in the $0-20 \mathrm{~cm}$ plough soil horizon (Figure 2). This range was mainly consistent with previous report demonstrating the carbon stocks declined by $59 \%$ after land changes from pasture to crop at a global scale (Guo and Gifford, 2002), and it was wider than Wu's estimation which clarified a SOC loss of $10-40 \%$ in the cultivated soils relative to their non-cultivated counterparts in China (Wu et al., 2003).

In the present study, the SOC losses up to $60 \mathrm{~cm}$ depth ranged from 1.13 to $9.25 \mathrm{~kg} \mathrm{C} \mathrm{m}^{-2}$ in the croplands in comparison with the grasslands over about 20 years. Wind erosion can result in a considerable amount of soil loss and deposition. Potential soil carbon losses and gains from wind erosion depend on the carbon content of erodible particles and aggregates. Cultivation also caused a significant decrease in total $\mathrm{N}$ by about $64 \%$ in the upper soils. Previous studies have also reported a reduction in total N level by soil cultivation (Raiesi, 2006; Su et al., 2009). The loss of SOC can result in reduced quantities of $\mathrm{N}$. Cultivation of native grasslands caused marked changes in the SOC and available nutrients. Usually, soils from cropped lands are much lower in organic $C$ and other nutrients than comparable soils from virgin areas (Srivastava and Singh, 1989). The soil nitrogen losses can be due to removal by crops. In our study region, the farmers harvested all of the above-ground biomass, including the seeds and straw. Soil desertification and wind erosion also contributed to the loss of nitrogen. In recent decades, vegetation degradation, soil desertification and wind erosion were severe in the agro-pastoral econtone of Northern China. All these variables would disturb the assessment for SOC in this region (Wang et al., 2008).

\section{Conclusion}

Soils play an essential role in carbon cycling in terrestrial ecosystems. Land uses affect both $\mathrm{SOC}$ storage and $\mathrm{CO}_{2}$ exchange between soils and the atmosphere. The present study investigated the effects of different types of grassland conversion into cropland in the Bashang area. Conversions of different grasslands and subsequent tillage practices resulted in increased soil bulk density and temperature; decreased SOC and total N. On the average, the conversion of grasslands to croplands induced a moderate loss of SOC in $0-60 \mathrm{~cm}$ soil depth over about 20 years in an agro-pastoral ecotone of Northern China.

Deterioration of soil properties resulting from indiscriminate cultivation followed by wind erosion processes might occur in the semiarid, erosion-prone Northern China. To conserve the present status, potential conversion should be banned in both zonal and intrazonal grassland, the zonal grassland should be enforced "turning cropland to grassland" policy, and the intrazonal grassland be reasonably used.

\section{ACKNOWLEDGEMENTS}

The funding of this work was provided by National High Technology Research and Development Program of China (NO. 2006AA10Z250). The authors extend their immense appreciation to the anonymous reviewers for providing critical reviews and helpful comments on the manuscript. We also express our sincere thanks to Ph.D. Yan-Min Fan, Prof. Yu-Guang Bai and Prof. Jiang-Wen Fan for their constructive suggestions and revision of the manuscript.

\section{REFERENCES}

Cambardella CA (1994). Carbon and nitrogen dynamics of soil organic matter fractions from cultivated grassland soils. Soil Science society of America 58: 123-130.

Chen L, Gong J, Fu B, Huang Z (2007). Effect of land use conversion on soil organic carbon sequestration in the loess hilly area, loess plateau of China. Ecol. Restoration, 22: 641-648.

Chen ZQ, Zhu ZD (2001). Development of land desertification in Bashang area in the past 20 years. J. Geogr. Sci. 11(4): 433-438.

Chepil WS (1956). Influence of moisture on erodibility of soil by wind. Soil Sci. Soc. Proc. 20: 288-291.

Davidson J, Fenton G, Pinson D (1967). Changes in organic matter and bulk density with depth under two cropping system. Agron. J. 59: 375-378.

Dilly O, Blume HP, Sehy U, Jimenez M, Much JC (2003). Variation of stabilized, microbial and biologically active carbon and nitrogen in soil under contrasting land use and agricultural management practices. Chemosphere, 52: 557-569.

Evrendilek F, Celik I, Kilic S (2004). Changes in soil organic carbon and other physical soil properties along adjacent Mediterranean forest, grassland and croplands in Turkey. J. Arid Environ. 59: 743-752.

Falkowski P, Scholes R, Boyle E (2000). The global carbon cycle: a test of our knowlege of earth as a system. Science, 290: 291-295.

Frank AB, Tanaka DL, Hofmann L, Follett RF (1995). Soil carbon and nitrogen of Northern Great Plains grasslands as influenced by long-term grazing. J. rangeland manage. 48: 470-474.

Guo L, Gifford R (2002). Soil carbon stocks and land use change: a meta analysis. Global Change Biol. (8): 345-360.

Hai CX, Zhou XC, Li XJ (2005). Wind erosion is influenced by way of land using and soil surface humidity changing in Spring in Bashang region of Hebei Province. J. Soil Water Conserv. 19(2): 29-32.

Han JG, Sun QZ, Ma CH (2004). Ecotone sustainable development of agriculture and animal husbandy technology. Beijing, Chemical industry press.

Honghton RA, Hackler JL, Lawrence KT (1999). The U.S. carbon budget: contributions from land-use change. Science, 285: 574-578.

ISSCAS (1978). Physical and Chemical Analysis Methods of Soils.

Lal R (2002). Soil carbon dynamics in cropland and rangeland. Environ. 
Pollut. 116: 353-362.

Lal R (2004). Soil carbon sequestration impacts on global cliamte change and food security. Science, 304: 1623-1627.

Li RF, Zhao LY Zhang YH, Zhang TH, Shirato Y (2004). Wind erosion and airborne dust deposition in farmland during spring in the Horqin Land of eastern Inner Mongolia, China. Soil Tillage Res. 75: 121-130.

Liu $\mathrm{H}$, Zhang $\mathrm{WH}$, Wang $\mathrm{K}$ (2009). Effect of reclamation on soil properties of zonal and intrazonal grasslands in agro-pastoral ecotone. Trans. CSAE 25(10): 272-277.

Nimisha T, Sigh RS (2007). Cultivation impacts nitrogen transformation in Indian forest ecosystems. Nutrient Cycling Agroecosyst. 77: 233-243.

Raiesi $F$ (2006). Carbon and $N$ mineralization as affected by soil cultivation and crop residue in a calcareous wetland ecosystem in Central Iran. Agric. Ecosyst. Environ. 112(1): 13-20.

Srivastava S, Singh J (1989). Effect of cultivation on microbial carbon and nitrogen in dry tropical forest soil. Biol. Fertil. Soils (8): 343-348.

Su YZ, Liu WJ, Yang R, Chang XX (2009). Changes in Soil Aggregate, Carbon, and Nitrogen Storages Following the Conversion of Cropland to Alfalfa Forage Land in the Marginal Oasis of Northwest China. Environ Manage. 43:1061-1070.
Wang ZP, Han XG, Li LH (2008). Effects of grassland conversion to croplands on soil organic carbon in the temperate Inner Mongolia. J. Environ. Manage. 86(3): 529-534.

Wilson AT (1978). Pioneer agriculture explosion and CO2 levels in the atmosphere. Nature, 273: 40-41.

Wu H, Guo Z, Peng C (2003). Land use induced changes of organic carbon storage in soils of China. Global Change Biol. (9): 305-315.

Xiao HL, Zhao X, Zhao WZ (1998). Study on Uap-Ustic Isohumisol degradation under farming in Hebei, China. Acta pedologica sinica 35(1): 129-134.

Xu B (1997). Soil wind erosion on Horqin desert and its control measures. J. Desert Restoration 17: 7-14.

Zhang X, Xu D (2003). Potential carbon sequestration in China's forest. Environ. Sci. Policy (6): 421-432.

Zhao HL, Zhao XY, Zhang TH (2000). Causes, processes and countermeasures of desertification in the interlocked agro-pastoral area of Northern China. J. Desert Res. 20: 22-28. 